\title{
The role of negotiation about cultural issues on the ESP teachers' cultural identity development: A narrative inquiry
}

\author{
Naser Rashidi - Hussein Meihami
}

DOI: $10.18355 /$ XL.2019.12.02.10

\begin{abstract}
Developing teachers' cultural identity is assumed to have remarkable roles in teachers' professional development. Hence, the thrust of this study was to investigate the role of negotiation about cultural issues on the cultural identity development of the novice and experienced English for Specific Purposes (ESP) teachers. To that end, a narrative approach was employed to track down the cultural identity development of four novices and two experienced ESP teachers. The narratives authored by the ESP teachers were analyzed within Wenger's (1998) theory of community of practice. The results of the narrative analysis showed that negotiation about cultural issues has a constructive role in the cultural identity development of the novice and experienced ESP teachers. However, the narrative analysis indicated that there were some differences in the cultural identity construction of the novice and experienced ESP teachers. These differences were about their perspectives toward the knowledge they obtained in negotiation and the approaches which they implemented to reflect on the cultural issues in ESP classes. Both novice and experienced ESP teachers, nevertheless, followed the same path of alignment regarding their cultural identity development. Thus, it can be concluded that the ESP teachers can consider negotiation about cultural issues as a way to conjoin in a community of practice to develop their cultural identity in the ESP classes.
\end{abstract}

Key words: cultural identity, negotiation, narrative inquiry, ESP teachers, teacher education

\section{Introduction}

It is undeniable that language teachers' professional development has been, every now and then, influenced by educational changes. These changes which are made and implemented by educational systems aim to address different aspects of teachers' professional development. Teacher identity can be called as one of the central issues to adapt to these changes (Kubanyiova, Crookes, 2016; Tao, Gao, 2018). Teachers need to construct and reconstruct new identities to be in line with the current teaching mainstream (Xu, 2014). Hence, teacher identity has recently become a special arena of research (Zuengler, Miller, 2006) manifested in the theses, dissertations and published papers in different journals such as Journal of Language, Identity, and Education (Rashidi, Meihami, 2017; Norton, 2013). This is also true for the English for Specific Purposes (ESP) teachers who teach English to the students of different disciplines. ESP teachers encounter different identity struggles in their classes due to the higher content knowledge of ESP students comparing to the ESP teachers (Tao \& Gao, 2018), the subject matter knowledge (Chang, 2014; Wu, Badger, 2009), etc. Furthermore, ESP teachers may ask themselves about the level of subject matter knowledge they should possess to be successful in teaching ESP. Such identity struggles turn into a more controversial question for the ESP teachers which askes for the role of cultural issues in the ESP classes and how to treat them. Consequently, addressing the cultural identity of the ESP teachers and the process which ESP teachers construct and reconstruct their cultural identity is of utmost importance. That said, it is critical to know the place of culture in ESP context; consequently, we addressed the issue as follow.

XLinguae, Volume 12, Issue 2, April 2019, ISSN 1337-8384, eISSN 2453-711X 


\section{Culture in ESP Context}

Compared to teaching English for general purposes, the concept of culture in the ESP context has been approached scarcely. The review of the recent decade research on the conception of culture in the ESP context shows that there is a paucity of publication both theoretically and empirically in this regard. However, according to Connor and Rozycki (2013), two basic conceptions regarding culture in the ESP context are worth mentioning. The first theoretical conception of culture is based on anthropology definition of culture which believes that culture is "the way of life of the people" (Mathews, 2000: 2). In this definition, culture is a static concept transferred genetically. However, in a more recent and modern definition of culture, it is "emerged from criticism that the traditional formulation easily stereotypes those considered to be different" (Connor, Rozycki, 2013: 1). In this view, the dynamic and complex nature of culture is evident. Teaching in ESP contexts is not culturally neutral and as Barron (1991) states "there is an independent scientific culture that is the same all over the world, which is secondary to particular cultures" (p. 176). Accordingly, although every culture may have its principles for doing a special activity, for example, trading, there is a universally accepted set of principles for that act; leading people who know those principles to act, irrespective of their own culture, based on the universal culture. This is related to the concept of textualization used by Barron (1991) in which each and every specific field brings some new cultural issues to the real world which lead the ESP instructors to do something more than mere teaching linguistic input. In ESP classes, consequently, the ESP teachers need to address the cultural issues regarding the disciplines which they teach through the medium of the English language. Culture in the ESP contexts tries to conjoin people of different primary cultures to a new secondary culture as Widdowson (1979: 51) states

... the concepts and procedures of scientific inquiry constitute a secondary cultural system which is independent of primary cultural systems associated with different societies. So although, for example, a Japanese, and a Frenchman, have very different ways of life, beliefs, preoccupations, preconceptions, and so on deriving from the primary cultures of the societies they are members of, as scientists, they have a common culture. In the same way, I take it that the discourse conventions which are used to communicate this common culture are independent of the particular linguistic means which are used to realize them.

Scrutinizing the quotation and going through the two given definitions of culture in the ESP context, one can argue that the role of ESP teachers in the ESP classrooms is more than what they do in the general English classes regarding cultural issues. That said, it seems that an ESP teacher should accept and construct an identity based on which he/she can come up with not only different general cultural issues in ESP classrooms, but also with the ESP related cultural issues in these classes. As such, in the first step, a review of the language teacher's identity should be done to let us know about the recent developments regarding the concept of identity in this realm of study.

\section{Language Teacher's Identity}

Since the term identity is not unidirectional (Bilgen, Richards, 2015), it is not easy to provide a "one-size-fits-all" definition for it. However, the definition provided by Norton (2013) can be considered as comprehensive in which identity is described as "how a person understands his or her relationship to the world, how that relationship is constructed across time and space, and how the person understands possibilities for the future" (p. 45). When considering the definition provided by Norton (2013), we can state that the concept of "negotiating self" can be seen through it. Negotiating self 
refers to the potentiality that one has to convey his/her beliefs, values, and thoughts in different social networks. Consequently, as Preece, (2016: 3) declares, identity is a socially constructed phenomenon which is the "result of the mobility and diversity that has arisen in the social worlds of the physical and digital world due to the processes of globalization in late modernity." It means that identity has got an everchanging essence base on which the teachers construct, co-construct, and reconstruct their current identity. Nevertheless, researchers (e.g., Gu, Benson, 2015; Edwards, Burns, 2016; Trent, 2010; Yuan \& Lee, 2015) believe that it is not easy for teachers to negotiate their identity in the process of identity construction and reconstruction. These struggles may be due to different perceptions which teachers have about the understandings, professional engagements, and relationships of their "new" identity (Edwards, Burns, 2016).

The notions of "being", "doing" and "becoming" are in direct relationship to identity construction (McNaughton, Billot, 2016). The current state of a teacher's identity and what that teacher's attitudes, assumptions, beliefs, and values are, make the teacher's identity. Besides, doing is associated with how those belongings impose their effects on a teacher's transmission of identity to a new identity. More often than not, the process begins with being, then continues with doing, and finally reaches becoming or the state in which a teacher establishes a new identity. This process, as Korhonen and Törmä (2014) believe, has a critical role in the teachers' identity construction. The understanding of this process will help teachers to figure out their own identity and also other's identity (Bakhtin, 1990). It means that a dialogic understanding of the mentioned process of identity construction is required for the teachers to construct and reconstruct their own identity in different teaching contexts. Negotiation of self can be applied to each of the stages of this process. For instance, in being, one can negotiate on the belongings he/she has, and in doing, that person can use a different medium to address his/her identity. Moreover, in the final level of identity formation, becoming, one can negotiate on how to digest and implement a related concept in his/her selfidentity.

Language teachers have different roles in their classrooms which origin from their identity. More often, it is not easy for the language teachers to deal with multiple identities due to the struggle which exists between their current identity and the one they should construct (Tao, Gao, 2017; Tsui, 2007). For instance, it is not easy for language teachers to deal with being in different social positions, or when they ask to act as teacher-researchers (Borg, 2017; Whitsed, Volet, 2013). The studies conducted on the identity construction of language teachers have paid attention to two main contexts: personal and institutional. While in the personal context teachers' own schooling experience and the impact of their family are focused (Bukor, 2015; Flores, Day, 2006; Gu, Benson, 2015), in the institutional context their thoughts and beliefs about their profession construct their identity (Pennington, 2014). That said, the process of back and forth in which the teachers involve and make their identity open to negotiation. The discussion of negotiation will be approached with more care when teachers' cultural identity will be addressed. Given that, in the next section, we will, first, review the related concepts about language teachers' cultural identity, then, negotiation of cultural identity will be addressed.

\section{Language Teachers' Cultural Identity}

Although language teachers' identity has been investigated and described in many studies, language teachers' cultural identity has been rarely investigated (Fichtner , Chapman, 2011). Hall (1996) refers to cultural identity in terms of gaining "new ethnicities." It means to deal with new, and most of the time, different cultural issues as new options to recognize experiences without homogenizing them. Ennaji (2005)

XLinguae, Volume 12, Issue 2, April 2019, ISSN 1337-8384, eISSN 2453-711X 
states that cultural identity is the feeling of belonging to a special group as a part of one's self-perception of his/her nationality, ethnicity, social class, generation, locality, etc. Ennaji (2005) continues that cultural identity is, then, both the characteristic of one's self and that of the related group. The description has in itself the notion of negotiation of cultural identity. According to the researchers (Ennser-Kananen, Wang 2013; Fichtner, Chapman 2011; Menard-Warwick, 2011) the negotiation of cultural identity or, in their words, intercultural communication is of utmost criticality in construction and reconstruction of teachers' identity; moreover, it will help teachers to deal with cultural issues that happen in their classrooms. However, establishing a new cultural identity, studies show, is not without struggles on the part of language teachers. As Martel and Wang (2015) point out "tensions and struggles are common themes in the construction of language teachers' bi- or multi-cultural identities" (p. 239). Such conflicts and tensions have been shown in the study conducted by Fichtner and Chapman (2011) in which the English language student-teachers state that their primary identity is in association to their national identity while their secondary identity is in association to the language they teach. Fichtner and Chapman's (2011) study revealed that "foreign language instructors engage with their cultural affiliations intellectually, by embracing but not embodying 'the other' culture" (p. 116). Moreover, Zabetipour and Ashraf Baghi (2015: 334) conducted a research to investigate "the relationship between EFL teachers' cultural identity and their length of experience in English language teaching to find out whether years of experience in teaching English would have any impact on the degree of their home culture attachment." However, the results of their study showed that there was no significant relationship in this regard.

By reviewing the literature regarding English language teachers' cultural identity, one can state that much of what has been sated is about "the limitations of their backgrounds to their difficulties in addressing culture in the L2 classroom" (MenardWarwick, 2008: 620). It is important to note some issues when focusing on cultural identity and its relationship to English language classrooms. These issues, according to Duff and Uchida (1997: 452), are the fact that "foreign language teachers and students commonly discuss the social and cultural aspects of other ethnolinguistic groups, particularly those associated with the target language...". Moreover, it is undeniable that the "problems may arise when teachers' or students' identities and beliefs related to gender roles, nationality, ethnicity... or local culture" (Duff \& Uchida, 1997: 452). Furthermore, as Duff and Uchida (1997: 452), it may be due to the reason that "the English language teaching industry is not culturally, ... neutral; rather, in the international (EFL) sphere it plays a powerful role in the construction ... identities among teachers and students." This shows that because of the multifaceted institutional context which English language teaching has, the cultural identity of English language teachers may be subject to reconstruction. When we think of the ESP context in which English teachers have complexities related to the disciplinespecific context along with many other issues such as focusing on the special needs of the program and the ESP learners, a teacher may have fluctuating roles such as acting as a content and language teacher, or as a specialist teacher-researcher, etc.

The cultural identity construction and reconstruction of the language teachers in general, and ESP teachers, in particular, has a relationship with the concept of cultural identity negotiation. Negotiation can be defined as "one of the possible means of getting things accomplished" (Strauss, 1978: 11) by different actors. The metaphor of actors has been used, here, since actors, or in this study the ESP teachers, have an impact on one another when they interact over time; as individuals interact in the society and influence each other step by step. Different theories such as identity management theory (Imahori, Cupach, 2005), identity negotiation theory (Stella TingToomey, 2005), cultural contract theory (Jackson, 2002), co-cultural theory (Orbe, 1998), cultural identity negotiation theory (Collier and Thomas, 1988) addressed the 
importance of cultural identity negotiation. The gist of these theories can be summarized as follows.

First, cultural identity is not always negotiable. It can be reasoned due to some factors such as the quality of interaction, one's position in dominant or under-represented groups, and the quality of cultural identification. The second point regarding cultural identity in the examined theories is that the value one ascribes for his/her self-image which includes values, beliefs, and assumptions can be highly important in negotiating cultural identity. If one sees his/her self-image in accordance with others' cultural identity, there will be more chance of negotiation of cultural identity. The third point is that individuals do not have the same strategic options to share their cultural identity in different contexts; meaning that for each individual there exists different options to negotiate his/her cultural identity. The fourth point is that the negotiation of identity conducted by individuals aims to establish mutual parties. Accordingly, the negotiation of cultural identity, implicitly but continuously, make some cultural identities to be more dominant in the community. Finally, it is worth mentioning that literacy of the cultural identity of different parties is necessary for individuals to find commonalities in each other's cultural identity to be able to negotiate their cultural identities.

\section{Rationale for this Study}

English for specific purposes deals with teaching different disciplines through English which finds an important place in language pedagogy. The interaction among the scholars of different disciplines around the world is the central reason for having English as the lingua franca of specific disciplines; helping to disseminate disciplinary knowledge with stressing down the interaction failure. One can argue, hence, that science is not culturally neutral and as Barron (1991: 176) states "there is an independent scientific culture that is the same all over the world, which is secondary to particular cultures." Given that, the cultural identity of ESP teachers confronts with different cultural issues which can be influenced by those cultural issues or influence them. As can be implied from what has been already stated, cultural identity can be either negotiable or unnegotiable when addressing it for language teachers. It can be due to the self-image a language teacher has about the values, assumptions, and beliefs around him/herself. On top of these, each language teacher has his/her own strategies of sharing their cultural identity. When considering these issues for the ESP teachers, one can state that there should be conducted a study to track down the cultural identity construction and reconstruction of ESP teachers. Moreover, the issues mentioned already may be different for the novice and experienced ESP teachers. That said, the purpose of the current study was to investigate, qualitatively, the impact of negotiating cultural issues which the novice and experienced ESP teachers confronted in their profession on their cultural identity construction and reconstruction.

\section{Method \\ Participants and Setting}

The foremost motivation for conducting this study was to address the novice and experienced ESP teachers' cultural identity construction while they participated in negotiation programs. Expertise in L2 pedagogy has been the subject of many investigations from different perspectives (Johnson, 2005; Tsui, 2005). When putting these studies together, one can mention that the experienced L2 teachers are those with at least five years of teaching experience (Gatbonton, 1999; Gatbonton, 2008; Richards, Li, Tang, 1998; Tsui, 2003) while novice teachers are still in their teaching

XLinguae, Volume 12, Issue 2, April 2019, ISSN 1337-8384, eISSN 2453-711X 
training and have less than five years of teaching experience (Gatbonton, 2008). If we imagine a continuum indicating the novice teachers on its lower end and the experienced teachers on the higher one, we can say that the thinking and classroom performance and management of the experienced teachers, more often than not, is with fewer fluctuations. According to Gatbonton (2008: 162) observing fewer fluctuations in the teaching performance of the experienced teachers is due to the fact that "they already have had ample opportunities to deal with recurring issues and, consequently, have had occasions to retain what works and eliminate what does not." However, it is highly important to note that change can be seen in the later stages since the professional development of teachers never ends (Tsui, 2005). Novice teachers, in contrast, are more fluctuating regarding their teaching performance. It is because their knowledge has "more variable elements than stable ones, although, presumably, with time, the latter would continue to increase" (Gatbonton, 2008: 162). In the current study, since our participants were ESP teachers, their knowledge specificity needed to be taken into account. In other words, the ESP teachers teach English to the students of a specific discipline whose level of understanding of that discipline in terms of the related knowledge can be an index of measuring experience. That said, in the current study we used two criteria for dichotomizing novice and experienced ESP teachers: Years of teaching ESP experience and their level of understanding of the specific discipline. We prepared a scheme in which we assessed their 1) years of teaching ESP experience and 2) assumption about their understanding of the specific discipline. We gave the scheme to six ESP teachers purposefully selected. After analyzing their schemes, we understood that four of the ESP teachers were a novice and the other two were experienced. Of the four total number of the novice ESP teachers, three were male teachers and one was female. Moreover, the two experienced ESP teachers were male. The ESP teachers taught English to the students of nursing, humanity, and engineering. They all were $\mathrm{PhD}$ candidates or $\mathrm{PhD}$ graduates of Teaching English as a Foreign Language (TEFL). Finally, it is worth mentioning that the teaching experiences of the novice ESP teachers in an ESP context was about three years; and for the experienced teachers, it was around 13 years. Table 1 indicates the background characteristics of ESP teachers.

Table 1: Background characteristics of the ESP teacher

\begin{tabular}{|c|c|c|c|c|c|}
\hline$\overline{P s e u d o n y m}$ & $\begin{array}{l}\text { Educational } \\
\text { background }\end{array}$ & $\begin{array}{l}\text { ESP courses } \\
\text { taught }\end{array}$ & $\overline{\text { Gender }}$ & $\begin{array}{l}\text { Years of } \\
\text { teaching } \\
\text { (ESP) }\end{array}$ & $\begin{array}{l}\text { Novice/ } \\
\text { Experienced }\end{array}$ \\
\hline Saber & PhD in TEFL & $\begin{array}{l}\text { Business } \\
\text { management }\end{array}$ & Male & 10 & Experienced \\
\hline Ali & PhD in TEFL & Accounting & Male & 15 & Experienced \\
\hline Parmida & $\begin{array}{l}\text { PhD student } \\
\text { in TEFL }\end{array}$ & Nursing & Female & 3 & Novice \\
\hline Amir & $\mathrm{PhD}$ in TEFL & $\begin{array}{l}\text { Business } \\
\text { management }\end{array}$ & Male & 5 & Novice \\
\hline Radmehr & PhD in TEFL & History & Male & 2 & Novice \\
\hline Barbod & $\begin{array}{l}\text { PhD student } \\
\text { in TEFL }\end{array}$ & IT & Male & 2 & Novice \\
\hline
\end{tabular}

\section{Analytical Framework}

In the current study, we approached the notion of the cultural identity of the ESP teachers through Wenger's (1998) theory of community of practice. Based on this theory, learning is considered as the social participation phenomenon in which participants come together and engage in the "practices of social communities' and to construct 'identities in relation to these communities" (Wenger, 1998: 4). Wenger, 
McDermottt, and Snyder (2002: 4) describe the community of practice as "groups of people who share a concern, a set of problems, or a passion about a topic, and who deepen their knowledge and expertise in this area by interacting on an ongoing basis." Given that, one can say that since people have got shared concerns, problems, passions, etc. regarding different topics, they can be the members of different community of practices. When negotiation is central to identity construction through the theory of community of practice, Wenger (1998) pinpoints three modes of belonging: Engagement, imagination, and alignment. They were the main themes of our narrative analysis in this study. Below, we are discussing each of these modes of belonging.

Engagement. The notion of engagement is associated with communities of individuals' participation in a mutually negotiated activity in which the notion is more complex than the notion of groups or networks. According to Goodnough (2010: 168) "through ongoing negotiation, a joint enterprise develops over time, resulting in a shared repertoire ... that guides the community and provides the impetus for continued learning." Through engagement in the process of negotiation, people construct their identity.

Imagination. Wenger (1998: 176) defines imagination as "a process of expanding our self by transcending our time and space and creating new images of the world and ourselves." Imagination is the image created by a person about his/her circumstances in which he/she lives during different time and space. Consequently, imagination can contribute to the teachers to put themselves and their profession in different circumstances; which can assess their activity to be the teachers they like to be. Finally, it should be stated that imagination needs "flexibility and creativity to reinvent practices of communities and to create opportunities for novel learning" (Goodnough, 2010: 169).

Alignment. The third mode of belonging is alignment which is the stage "allowing the identity of a larger group to become part of the identity of the individual participants" (Trent, 2010: 155). When teachers see the practice and discourse of the community of practice, they put all their energy to reach the common goal of that community. Alignment has two sides involving negative and positive. On the negative side, for instance, a teacher who will be disempowered by the community of the practice, he/she participates in may follow the practice of the community without meaningful engagement which can have disruptive effects on the identity construction of that teacher. On the positive side, however, the teacher is provided with facilities to use his/her critical thinking to have a meaningful engagement with the community of practice.

\section{Teacher-authored Narratives}

The recent decades have witnessed a growing interest in the use of narrative inquiry in examining language teachers' identity construction (Johnson, Golombek, 2011; Norton, Early, 2011; Tsui, 2007). This is due to the strong potentiality of the narrative inquiry in helping the researchers to examine the teachers' identity development over various space and time (De Costa, 2015). Moreover, narratives can provide "rich insider accounts of the complex day-to-day work for educational practice as well as how practitioners theorize and understand their work from the inside" (CochranSmith, Lytle, 2009: x). The insider or emic perspective means that the researchers collect the information from the teachers involving in the process of identity construction; consequently, in a step-wise manner, they delve into the process of identity construction with the help of the teachers. In this study, a narrative epistemology in which one's activities and experiences are manifested in his or her narratives was applied. The narrative epistemology recognizes that narratives, by their

XLinguae, Volume 12, Issue 2, April 2019, ISSN 1337-8384, eISSN 2453-711X 
very nature, are not meant to describe phenomena objectively, but rather to expose how people's understandings of phenomena are infused with interpretation" (Johnson, 2007: 178). Moreover, since narratives have the feature of being chronological, one can go through the stance of teachers' ideas about an issue by examining them during different points of time (Rashidi, Meihami, 2017). It is worth mentioning that to be more reflexive and to deserve the due sensitivity to the production of the narratives by the ESP teachers (Bilgen, Richards, 2015), we asked them to choose their preferred language, either English or Persian, to write down their narratives.

\section{Data Collection and Analysis Procedure}

During eight months, we negotiated cultural issues with the six ESP teachers through different mediums such as academic papers, social network discussions, and face to face discussions. Every time, we asked the ESP teachers to write narratives about their cultural issues in their classrooms. It should be stated that during the eight months, the novice and experienced ESP teachers wrote eight narratives for us. After each session of negotiation and interaction of cultural issues, the researchers asked the ESP teachers to deliver their written narratives in less than one month. Finally, all of the narratives produced by the ESP teachers gathered in different profiles in which each profile was specified to one of the teachers.

To analyze the narratives, we went through the principles of ethnographic semantics which focuses on the meanings produced in the narratives (Spradley, 1979). Ethnographic semantics is associated with "those aspects of meaning in a language that are culturally revealing. It is directed towards words as a means rather than an end" (Colby, 1966: 3). De Fina and Georgakopoulou (2012) mention two paradigms of narrative analysis when identity is examined: Biographical and Interactionally oriented approaches. The biographically oriented narrative analysis considers that the "narrative has itself a positive effect on self-identity ... people may hold different and sometimes conflicting images of themselves; biographical approaches still tend to see the process of life-storytelling as achieving integration through different mechanisms" (De Fina, Georgakopoulou, 2016; p. 352). According to Gregg (2011), a biographical approach to narrative analysis focuses on the cognitive and psychological implications; including an autobiography. The interactionally oriented approach to narrative analysis pays attention to the interactions among narrators, co-narrators, and audiences. According to De Fina and Georgakopoulou (2016)

Cognitive and psychological issues are not at stake here, because most interactionists tend to concentrate on the social rather than mental aspects of all semiotic processes since they believe that it is through such social constructions that ideas and images are created and circulated. Identity, therefore, is literally in the doing, rather than in the thinking, and it is this doing that is amenable to observation for discourse analysts. (p. 352-3).

Since we went through the cultural identity construction of the novice and experienced ESP teachers by negotiation and we had different interactions with them, it was appropriate to use interactionally oriented approach to analyze the narratives produced by the ESP teachers. The reason behind which we used interactionally oriented approach to data collection and analysis was that, as stated previously, we had some interactions on the cultural issues related to the ESP classes with the ESP teachers and after those interactions, we asked them to produce their narratives. We conducted the ethnographic semantics and categorized the obtained results based on Wenger's (1998) theory of community of practice.

\section{Rigor of the Study}


The consistency of the data and valid inferences are very important in qualitative research; called rigor of the qualitative study. The rigor of the current study was approached using three methods: Member checking and method triangulations for the credibility of data analysis and inter-rater agreement for dependability (Ary et al., 2014). That said, whenever parts of the narratives authored by the teachers were vague, we asked them to explain those parts for us. Furthermore, method triangulation which means to use more than one method in data collection and analysis was followed to enhance the credibility of the study. The important assumption of method triangulation is that the combination of methods leads to better evidence. That said, in the current study the lead researcher used both written narratives and three observation sessions of the ESP classrooms in which the novice and experienced ESP teachers instructed the ESP students. Given that, the researchers used the observation data when they wanted to obtain the final themes. Moreover, two raters analyzed the narratives based on the theoretical framework. Before starting to analyze the narratives, the two raters participated in training sessions where they learned about the terms of analysis. These training sessions led to more analysis agreement between the two raters.

\section{Results and Discussion}

In the following section, we have categorized the analysis and their related discussions based on the novice and experienced ESP teachers.

\section{Analysis of the Experienced ESP Teachers' Narratives}

\section{Engagement in the Narratives of Experienced ESP Teachers}

It seems that the experienced ESP teachers considered negotiation about cultural issues as empowerment for the previous experiences they had on managing cultural issues in their classrooms. This negotiation was also a way to 1) engage in a community whose main aim was to develop their cultural identity and 2) engage more easily and with more confidence with the cultural issues of their classroom. Ali stated in his narrative that

Excerpt \#1

... during the negotiation sessions either it was in the form of debates and discussion or reading academic papers ... I found an adherence toward joining a group for developing my cultural identity management in my classrooms ... I think it is a necessary program (He Always Called the Negotiations as In-Service Programs in the Face to Face Discussions) for even teachers with a high level of teaching experiences ...

Saber, another male participant, whose ESP teaching experience was 10 years declared that

Excerpt \#2

I have the experience of ESP classes with myriad cultural variations since I teach as university instructor to the students of business management ... the students are from different parts of Iran with different cultural background ... Now, I teach ESP for about 10 years, however, $I$ have problems with managing cultural issues in my classrooms ... it is because if the fact that I want to be a humanitarian teacher and come up with all variations among them, cultural variations of my students to teach them ESP for their life and discipline ... my confidence now is developed since my cultural identity awareness has been improved ...

It can be argued from the two excerpts mentioned above that the experienced ESP teachers think of negotiation about cultural issues as a way to develop their cultural identity (Tao, Gao, 2018) for managing their classroom cultural issues. That said,

XLinguae, Volume 12, Issue 2, April 2019, ISSN 1337-8384, eISSN 2453-711X 
through engagement in negotiation on cultural identity, the experienced ESP teachers develop their potentiality of addressing cultural issues in their classes. It is because engagement in negotiation will help them to negotiate cultural meaning in different perspectives (Goodnough, 2010). As it can be seen through the second excerpt, the negotiation of meaning on cultural issues which finally develops the cultural identity of the experienced ESP teachers is two-fold: First of all, the experienced ESP teachers joined a community of practice. Moreover, when they went to their classes they try to negotiate cultural meaning with their students; this time in real practice.

Through the process of negotiating cultural issues, the experienced ESP teachers' awareness about the role of culture in ESP teaching developed; helping them to develop their cultural identity in this regard. Below are parts of the narratives authored by Ali and Saber in excerpts 3 and 4, respectively.

Excerpt \#3

...for me the interesting point was that, after 15 years of ESP courses, ESP and EAP [English for Academic Purposes] have their conceptualization of culture ... when the research gave me a paper on how culture is approached in the ESP paradigm, I found that many of my cultural issues I had in my ESP classroom can be solved ...

Excerpt \#4

... and culture has its own role in ESP teaching ... now, when I teach business capital to my students can ask their own cultural background about this concept and ask them to compare and contrast their own cultural concepts with those of they read and learn in the classroom...

It can be stated that through negotiation about cultural issues, the experienced ESP teachers came to the understanding that ESP has its cultural conception (Barron, 1991; Connor, Rozycki, 2013). Negotiation on cultural issues had developed their awareness about cultural issues which were in direct relationship to the ESP itself. The experienced ESP teachers understood that the engagement of the cultural identity of the students with different background and that of the ESP concepts could be regarded as a medium of discussion through which ESP students would be motivated and learned the ESP concepts. These parts of the narratives produced by the experienced ESP teachers showed that their cultural identity regarding using cultural issues of the ESP courses developed.

Imagination in the Narratives of Experienced ESP Teachers

The narratives produced by Ali and Saber were analyzed for their imagination. It is believed that after engaging in the negotiation of meaning, teachers will enter the imagination phase which requires them to be more risk takers, to reflect more on their teaching practice, and to create new teaching method for themselves (Goodnough, 2010). The analysis of narratives showed that the experienced ESP teachers created new methods of teaching, especially regarding cultural issues. Ali and Saber stated in excerpts 5 and 6 , respectively, that

Excerpt \#5

... from now on, I find a great method to help the ESP learners to discuss in the classroom ... whenever I teach a special term of their discipline which can have a cultural discussion on it, I will ask my students to discuss it based on their own culture ...

Excerpt \#6

Negotiation on cultural issue leads me to think to create a model of discussion for my students ... each student should talk about his/her discipline special concepts from the point of view of his/her own culture and the international point of view ... Through negotiation on the cultural issues, it can be argued that the experienced ESP teachers reconstructed their identity from someone who received teaching methods from different sources to one who self-created his/her teaching methods (Johnson \& Golombek, 2011; Zand-Moghadam, Meihami, 2016). Moreover, the analysis of the narratives produced by the experienced ESP teachers indicated, implicitly, that they 
would like to reflect on their teaching methods regarding their cultural identity in the future. The following excerpts are narratives by Ali and Saber in excerpts 7 and 8, respectively, showing their likelihood to reflect upon their teaching methods.

Excerpt \#7

... I think even through creating a portfolio on the teaching methods I used to increase the cultural identity of my student through the negotiating teaching method can help me to make it even better and more applicable ...

Excerpt \#8

; however, care should take into account regarding my teaching model ... I should talk to other teachers to make it more appropriate ...

Alignment in the Narratives of Experienced ESP Teachers

Alignment is the motivation to continue the activities which are affiliated with a special community. To put it in another way, when teachers try to broaden an activity or a set of activities in other contexts, their alignment to those activates is high, and they like to capture those activities as a part of their identity; resulting in identity construction. In the case of the current study, it came up that the two experienced ESP teachers liked to generalize their new perspectives regarding their own cultural identity to other contexts, especially to teaching English for general purposes. Below are parts of the narratives authored by Ali and Saber in excerpts 9 and 10, respectively.

Excerpt \#9

...I enjoy using cultural issues, after negotiation sessions, in my classes and I will try to make use of them in general English classes, too, even though I used culture for the topic of discussion in those classes, now, I know that cultural issue can also be the matter of discussion ...

Excerpt \#10

I will discuss the teaching model I created with my colleagues, and after making it more appropriate, I will use it in my other classes ... I also present it at the conference I will attend ... to other English related teachers ... however, I should consider the assigned program ...

One important point regarding alignment, observed in the narratives produced by Saber, is that the curriculum developers should spare enough room for the teachers to make them able to align their new established professional identity with practicing (Goodnough, 2010).

\section{Narrative Analysis of the Novice ESP Teachers}

\section{Engagement in the Narratives of Novice ESP Teachers}

The first interesting difference appeared between the experienced and novice ESP teachers was the fact that the novice ESP teachers thought that engagement in the negotiation about cultural issues empower them for their future classroom management, unlike the experienced ESP teachers who considered negotiation as empowerment for their previous experiences. To put it in another way, the novice ESP teachers considered the negotiation of cultural issues as a body of knowledge helped them in the future to run their classes; however, the experienced ESP teachers found engagement in the negotiation of cultural issues complementary to their previous knowledge of classroom management. Parmida, Barbod, and Amir mentioned this difference in their narratives in excerpts 11 to 13 .

Excerpt \#11

... and it is crystal clear for me that I can use the knowledge I gained in the engagement in the cultural issue negotiation in the future of classroom ...

Excerpt \#12

XLinguae, Volume 12, Issue 2, April 2019, ISSN 1337-8384, eISSN 2453-711X 
...in the future I will use the outcomes of the discussions I had about cultural issues in my classes ... I think they can act as a set of tools for making teaching easier ... and learning better...

Excerpt \#13

I think a teacher needs to be equipped with different teaching methods and facilities ... in my classes, I will use the things we discussed and studies about dealing with cultural issues ...

The reason for such considerations regarding negotiating cultural issues by the novice ESP teachers may be they are still in their first stages of teaching, and their teaching "container" is still open to new ideas.

The novice ESP teachers showed their awareness about the conception of culture and cultural issues developed after participation in the negotiation about cultural issues. Given that, the novice ESP teachers believed that they could negotiate on different cultural meanings in the ESP classrooms. Parmida, Barbod, Amir, and Radmehr pinpointed this issue in excerpts 14 to 17 .

Excerpt \#14

...I have never thought that ESP can have its own definition of culture ... I think the subject matters can be the content for developing ESP materials ...

Excerpt \#15

The foremost goal of ESP is to prepare disciplinary students for global communication ... if we can teach them culture in relation to their discipline we can help them a lot ...

Excerpt \#16

... now that I know that ESP has its own specific conception of the cultural issue I will try to learn the specific culture of the discipline I teach and use it in the classroom ...

Excerpt \#17

...negotiation of cultural issues had a wonderful output for me based on which I understood that each specific major could have its own culture ...

Negotiation on cultural issues pushed the novice ESP teachers to reconstruct their cultural identity through ESP related cultural issues in their classes. As Goodnough (2010) stated negotiation of meaning which happens when teachers engage in it. The novice ESP teacher, similar to their experienced counterparts, believed that they could use their students' background culture, the specific culture related to ESP, and their own culture, all together to help their students understand the specific subjects through English. Parmida and Amir stated this issue in their narratives in excerpts 18 and 19 , respectively.

Excerpt \#18

$\ldots$ in the future whenever I will be asked to teach an ESP course, I will try to combine culture related to that ESP course and teach my students ESP related cultural notions ...

Excerpt \#19

I will try to make an amalgamation of culture related to ESP, my students background culture, and my own culture to teach specific concepts ... I try to go through the negotiation of cultural meaning as we do it for us during ...

\section{Imagination in the Narratives of Novice ESP Teachers}

As stated earlier, imagination happens after negotiation in the process of teacher identity construction. It is about helping teachers to be more risk takers, to reflect more on their teaching practice, and to create new teaching method for themselves (Goodnough, 2010). None of the novice ESP teachers, unlike the experienced ESP teachers, mentioned such points in their narratives. However, in the narratives of the novice ESP teachers a sense of cautious could be seen; as can be seen in the following narratives authored by Parmida, Barbod, Amir, and Radmehr in excerpts 20 to 24 . 
Excerpt \#20

... I should say that I take care when I want to use cultural issues in the ESP classrooms... even though I will use them, I do not take the risk to allot the entire time of the class to that ...

Excerpt \#21

... although we had nice discussions on how to address cultural issues in the ESP classes in the negotiation sessions, I think that I need to search more for a method to help me ...

Excerpt \#22

...I wonder if there are any special approaches, methods, or techniques which I can use to address cultural issues in my ESP classes ...

Excerpt \#23

We need more discussion and negotiation through different sources to find out an appropriate method to come up with the cultural issues ...

As it can be seen through the above narratives, excerpts 20 to 23, the novice ESP teachers sought different methods which could help them to address cultural issues in the ESP classrooms. None of them considered their abilities to create their methods and approaches. As Gatbonton (2008) stated, novice teachers are in the teaching training stage of their profession, and their knowledge regarding teaching is in a continuous fluctuation. It can be stated that the novice ESP teachers of the current study did not establish their own professional identity. Consequently, they sought methods "out there" and did not reflect on their knowledge, yet. As a whole, it can be stated that negotiation of cultural identity does not lead to identity reconstruction of the novice ESP teachers when their identity as method constructor for addressing cultural identity in the ESP classes is at the center.

\section{Alignment in the Narratives of Novice ESP Teachers}

Finally, the narratives produced by the novice ESP teachers were analyzed for their alignment mode. The results of the analysis showed that the four novice ESP teachers, the same as the experienced teachers, actively wanted to distribute their awareness about cultural issues to their general English classes. The following narratives in excerpts 24 and 25 produced by the novice ESP teachers show this theme.

Excerpt \#24

$\ldots$ and if I can find an appropriate method to implement it, I will benefit from it in my general English classes ...

Excerpt \#25

I have two concerns about negotiating cultural meaning in my classes. The first is finding an approach to implement it in the classroom and the second is the curriculum allows us to do so ...

As Goodnough (2010) stated, it is very important that the curriculum of the teaching programs allow the teachers to establish their way of classroom management. One can say that this issue is more crucial for novice teachers. Since the knowledge of the novice teachers is in continuous fluctuating and due to the stress they have at the beginning of their teaching profession, they do not take the risk to create their own professional identity if they find out that the program limits them to the assigned principles.

\section{Conclusions and Implications}

The thrust of this study was to examine the role of negotiation about cultural issues on the cultural identity construction of novice and experienced ESP teachers. Through examining the cultural identity construction using Wenger's (1998) theory of community of practice, we understood that the cultural identity of the novice and

XLinguae, Volume 12, Issue 2, April 2019, ISSN 1337-8384, eISSN 2453-711X 
experienced ESP teachers reconstructed with regard to addressing cultural issues in the ESP classes. The results of the narrative analysis showed that the novice and experienced ESP teachers reconstructed their cultural identity about engagement, imagination, and alignment after participating in the negotiation of cultural issues through different mediums. The narrative analysis, moreover, showed some differences in the cultural identity construction of the novice and experienced ESP teachers. While, for example, the experienced ESP teachers considered negotiation on cultural issues as a complementary source for their previous experiences, the novice ESP teachers considered negotiation on cultural issues a set of tools empowering their future ESP teaching. Furthermore, the novice and experienced ESP teachers' imagination was different when they constructed their cultural identity. Owing to this, while the experienced ESP teachers reflected on their own produced methods for addressing cultural issues in their ESP classes, the novice teachers sought for finding "outside" methods which could help them to practice what they learned about cultural issues in their ESP classes. However, the results of the narrative analysis showed that the cultural identity construction of the novice and experienced ESP teachers went through the same path about alignment; in which both novice and experienced ESP teachers wanted to use the awareness which they obtained through negotiation in other instructional contexts.

The results of the narrative analysis of the current study indicated that the novice and experienced ESP teachers problematized the ESP related cultural issues in the negotiations they had on cultural issues; directing them to develop their cultural identity in the ESP classes. It is because the ESP teachers joined a community of practice (Yuan, Burns, 2016) in which they could address and problematize the cultural issues they confronted in their ESP classes. Moreover, this community of practice led them to conceptualize their cultural identity regarding cultural issues in the ESP classes; as it was the same when L2 teachers join a community of practice to conduct action research (Burns, 1999). Furthermore, it can be argued from the analysis of the narratives that both the novice and experienced ESP teachers constructed a new role for themselves based on which the cultural issues associated to ESP classes should be addressed. This issue can be related to what Tao and Gao (2018) state that "becoming an ESP teacher not only altered their instructional practices in the classroom but also transformed their professional lives, as reflected in the different frames of teacher identities" (p. 10). A difference should be mentioned here about the cultural identity development of the novice and experienced teachers in which the experienced teachers' cultural identity construction was less constrained by the institutional aspects such as the assigned curriculum comparing with the novice ESP teachers. According to Flores and Day (2006) the identity construction of the ESP teachers in general is, by its large, constrained by the institutional affairs.

It can be, implicitly, figured out through the analysis of the narratives authored by the ESP teachers that their primary problem which these teachers confronted is the contradiction existing between their current cultural identity and the one which they constructed after negotiation on cultural issues. The unstated question in their mind is on the role of culture in the ESP courses. They did not consider themselves as culture teacher since they did not consider any role for cultural issues in the ESP classrooms at the beginning of the negotiation programs. Such conflicts in identity construction ESP teachers can be addressed by Campion's (2016: 67) proposal in which "the learning never ends" for the ESP teachers. According to Hiver (2013), ESP teacher development needs to be extended beyond language teachers' education. By this token, going beyond language teacher education can be interpreted as both development in the ESP teachers' identity construction and disciplinary knowledge. Finally, since in the instructional contexts such as Iran in which the ESP teachers are those who have educated in TEFL and do not have any special disciplinary education, 
"the learning never ends" proposal for the ESP teachers should be taken into account with a higher level of importance (Stapleton \& Shao, 2018).

Based on the results we obtained from the analysis of the narratives authored by the novice and experienced ESP teachers, we propose a hypothesis regarding a threshold level after which the ESP learners can reconstruct their cultural identity in the ESP classes. Through the course of narrative analysis, we understood that the experienced ESP teachers went through engagement and imagination modes of belonging different from the novice ESP teachers. We think that the professional development of the novice ESP teachers is in direct relation to their professional identity construction (Tao, Gao, 2018) is still fluctuating between self and others; making the novice ESP teachers take care when reconstructing their cultural identity in their ESP classes. Based on this hypothesis, we assume at least five years of ESP teaching experience along with a fundamental understanding of disciplinary knowledge for the ESP language teachers to be able to construct their ESP related cultural identity. However, the hypothesis needs, doubtlessly, to be tested both qualitatively and quantitatively by further studies.

When the ESP teacher educator plan for cultural identity development of the ESP teachers, they should pay a deserved attention to internal and external supports. As Chan and Clarke (2014) declare, the policymakers need to provide an appropriate workplace for the teachers that allows them to negotiate meaning by joining to different communities of practice. That said, the ESP teacher educators should plan preservice and in-service programmes which contribute to the ESP teachers to foster "a teaching force of transformative intellectuals" (Johnson, 2007: 235) including related tools to support their educational experience and teaching resources. The ESP teacher educators, moreover, should provide some external supports for the ESP teachers, especially the novice ESP teachers, to be able to critically reflect upon their understandings of the negotiation on different meanings (Simon-Maeda, 2004; Tao \& $\mathrm{Gao}, 2018)$. One of the reflection approaches can be doing action research by the ESP teachers (Borg, 2017) or making the curriculum less rigid. These policies can help the ESP teachers find their work more meaningful and, as Trent (2015: 51) states, the feeling that their work is meaningful help them to try "different ways of becoming and being teachers." Consequently, the reflection will be the results of such meaningful work which should be the core of identity development programmes (Clarke, 2008). Finally, according to Tao and Gao (2018: 12) "it is important for educational administrators to build an incentive system that rewards ESP teachers for the extra effort and time, particularly for areas that require them to acquire subject knowledge" to help the ESP teachers to engage in the disciplinary discourse to understand the cultural issues and develop their cultural identity.

\section{Bibliographic references}

ARY, D. - JACOBS, L. C. - IRVINE, C. K. S. - WALKER, D. 2014. Introduction to research in education. London: Cengage Learning. ISBN: 978-1133596745

BAKHTIN, M.M. 1990. Art and answerability and edited by Michael holiest and vadimliapunov. Translated by Vadim Liapunov and Kenneth Brostrom. Texas: University of Texas Press. ISBN: 978-0292704121

BARRON, C. 1991. Material thoughts: ESP and culture. English for Specific Purposes, vol. 10, issue 3, pp. 173-187. ISSN: 0889-4906

BILGEN, F. E. - RICHARDS, K. 2014. Identity negotiations of TEFL teachers during a time of uncertainty and redundancy. In YL Cheung, S. B., Said, \& K. Park (Eds.). Advances and current trends in language teacher identity research, pp. 83-95, New York: Routledge. ISBN: 9781138025363

BORG, S. 2017. Action research and teacher identity. The 2016 Cambridge English/English UK Action Research Scheme, 2. ISSN: 1756-509X 
BUKOR, E. 2015. Exploring teacher identity from a holistic perspective: Reconstructing and reconnecting personal and professional selves. Teachers and Teaching, vol. 21, issue 3, pp. 305-327. ISSN: 1354-0602

CAMPION, G. C. 2016. 'The learning never ends': Exploring teachers' views on the transition from General English to EAP. Journal of English for Academic Purposes, vol. 23, pp. 59-70. ISSN: 1475-1585

CHAN, C. - CLARKE, M. 2014. The politics of collaboration: discourse, identities, and power in a school-university partnership in Hong Kong. Asia-Pacific Journal of Teacher Education, vol. 42, issue 3, pp. 291-304. ISSN: 1359-866X

CHANG, C. W. 2014. A qualitative inquiry into the dilemmas and challenges perceived by teachers in ESP instruction. LSP Journal, vol. 5, 1, pp. 97-111. ISSN: 1904-4135

CLARKE, M. 2008. Language teacher identities: Co-constructing discourse and community. Clevedon: Multilingual Matters. ISBN: 978-1847690814

COCHRAN-SMITH, M. - LYTLE, S. 2009. Inquiry as stance: Practitioner research for the next generation. New York: Teachers College Press. ISBN: 978-0807749708

COLBY, B. N. - AKHMANOVA, O. - ALBERT, E. M. - BANKS, E. P. - CHAFE, W. L. - CONKLIN, H. C. - KEESING, R. M. 1966. Ethnographic semantics: A preliminary survey [and comments and replies]. Current Anthropology, vol. 7, 1, pp. 3-32. ISSN: 0011-3204

CONNOR, U. - ROZYCKI, W. 2013. ESP and intercultural rhetoric. In B. PALTRIDGE S. STARFIELD (Eds.). The handbook of English for specific purposes, pp. 427-443, John Wiley \& Sons, Ltd, Chichester, UK. ISBN: 978-0470655320

DE COSTA, P. 2014. Tracing reflexivity through a narrative and identity lens. In Y. CHEUNG, L. - SAID, S. B. - KWANGHYUN, P. (Eds.), Advances and current trends in language teacher identity research, pp. 16-30. New Yotk: Routledge. ISBN: 9781138025363

DE FINA, A. - GEORGAKOPOULOU, A. 2012. Analyzing narrative: Discourse and sociolinguistic perspectives. London: Cambridge University Press. ISBN: 9780521715133

DE FINA, A. - GEORGAKOPOULOU, A. 2016. The handbook of narrative analysis. New York: John Wiley \& Sons. ISBN: 9781118458150

DOYLE, W. 1997. Heard any really good stories lately? A critique of the critics of narrative in educational research, Teaching and Teacher Education, vol. 13, issue 1, pp. 93-99. ISSN: 0742-051X

DUFF, P. A. - UCHIDA, Y. 1997. The negotiation of teachers' sociocultural identities and practices in postsecondary EFL classrooms. TESOL Quarterly, vol. 31, issue 3, pp. 451-486. ISSN:1545-7249

EDWARDS, E. - BURNS, A. 2016. Language teacher-researcher identity negotiation: An ecological perspective. TESOL Quarterly, vol. 50, issue 3, pp. 735745. ISSN:1545-7249

ENNAJI, M. 2005. Multilingualism, cultural identity, and education in Morocco. Springer Science \& Business Media. ISBN 9780387239804

ENNSER-KANANEN, J. - WANG, F. 2013, May-June. "I am combined": Chinese teachers constructing their identities as culture teachers. Paper session presented at the Seventh International Conference on Language Teacher Education, Washington, DC.

FICHTNER, F. - CHAPMAN, K. 2011. The cultural identities of foreign language teachers. L2 Journal, vol. 3, issue 1, pp. 116-140. ISSN: 1945-0222

FLORES, M. A. - DAY, C. 2006. Contexts which shape and reshape new teachers' identities: A multi-perspective study. Teaching and Teacher Education, vol. 22, pp. 219-232. ISSN: 0742-051X

GATBONTON, E. 1999. Investigating experienced ESL teachers' pedagogical knowledge. Modern Language Journal, vol. 83, issue 1, pp. 35-50. ISSN:1540-4781 
GATBONTON, E. 2008. Looking beyond teachers' classroom behaviour: Novice and experienced ESL teachers' pedagogical knowledge. Language Teaching Research, vol. 12, 2, pp. 161-182. ISSN: 1362-1688

GOODNOUGH, K. 2010. The role of action research in transforming teacher identity: Modes of belonging and ecological perspectives. Educational Action Research, 18(2), 167-182. ISSN: 0965-0792

GREGG, G. 2011. Identity in life narratives. Narrative Inquiry, vol. 21, issue 2, pp. 318-328. ISSN 1387-6740

GU, M. - Benson, P. 2015. The formation of English teacher identities: A crosscultural investigation. Language Teaching Research, vol. 19, issue 2, pp. 187-206. ISSN: 1362-1688

HALL, S. 1996. Introduction: who needs 'identity'?, In S. HALL and P. du GAY (Eds) Questions of cultural identity, pp. 1-17. London: SAGE. ISBN: 9780803978829

HIVER, P. 2013. The interplay of possible language selves in professional development choices. Language Teaching Research, vol. 17, issue 2, pp. 210-227. ISSN: $1362-1688$

JOHNSON, K. (Ed.) 2005. Expertise in second language learning and teaching (pp. 167-189). New York: Palgrave Macmillan. ISBN: 9781403920966

JOHNSON, K. E. - GOLOMBEK, P. R. 2011. The transformative power of narrative in second language teacher education. TESOL Quarterly, vol. 45, issue 3, pp. 486509. ISSN:1545-7249

JOHNSON, K.E. 2007. The sociocultural turn and its challenges for second language teacher education. TESOL Quarterly, vol. 40, issue 1, pp. 235-257. ISSN:1545-7249

KUBANYIOVA, M. - CROOKES, G. 2016. Re-visioning the roles, tasks, and contribution of language teachers in the multilingual era of language education research and practice. The Modern Language Journal, vol. 100(supplement), pp. 117118. ISSN:1540-4781

MARTEL, J. - WANG, A. 2015. Language teacher identity. In M. Bigelow C \& J. ENNSER-KANANEN (Eds.), The Routledge handbook of educational linguistics (pp. 289-300). New York: Routledge. ISBN: 9780415531306

MATHEWS, G. 2000. Global culture/individual identity: Searching for home in the cultural supermarket. New York, NY: Routledge. ISBN: 9780415206167

MCNAUGHTON, S. M. - BILLOT, J. 2016. Negotiating academic teacher identity shifts during higher education contextual change. Teaching in Higher Education, 21(6), 644-658. ISSN: 1356-2517

MENARD-WARWICK, J. 2008. The cultural and intercultural identities of transnational English teachers: Two case studies from the Americas. TESOL Quarterly, vol. 42, issue 4, pp. 617-640. ISSN:1545-7249

NORTON, B. 2013. Identity and language learning: Extending the conversation. London: Multilingual matters. ISBN-13: 978-1783090549

NORTON, B. - EARLY, M. 2011. Researcher identity, narrative inquiry, and language teaching research. TESOL Quarterly, vol. 45, issue 3, pp. 415-439. ISSN:1545-7249

PENNINGTON, M. C. 2014. Teacher identity in TESOL: A frames pespective. In Y. CHEUNG, L. - SAID, S. B. - Kwanghyun, P. (Eds.), Advances and current trends in language teacher identity research, pp. 16-30. New Yotk: Routledge. ISBN: 9781138025363

PREECE, S. 2016. The Routledge handbook of language and identity. New York: Routledge. ISBN: 978-1138774728

RASHIDI, N. - MEIHAMI, H. 2017. Addressing Cultural Identity through Negotiation: Analysis of Student-teacher-authored Narratives. Journal of Teacher Education for Sustainability, 19(2), 21-35. ISSN: 1691-5534

XLinguae, Volume 12, Issue 2, April 2019, ISSN 1337-8384, eISSN 2453-711X 
RICHARDS, J. C. - LI, B. - TANG, A. 1998. Exploring pedagogical reasoning beliefs. In J. C. RICHARDS (Ed.), Beyond training. New York: Cambridge University Press. ISBN: 978-0521626804

SIMON-MAEDA, A. 2004. The complex construction of professional identities: Female educators in Japan speak out. TESOL Quarterly, vol. 38, issue 3, pp. 405-436. ISSN:1545-7249

SPRADLEY, J. 1979. The ethnographic interview. New York: Holt, Rinehart \& Winston. ISBN: 0030444969

STAPLETON, P. - SHAO, Q. 2018. A worldwide survey of MATESOL programs in 2014: Patterns and perspectives. Language Teaching Research, vol. 22, issue 1, pp. 10-28. ISSN: 1362-1688

TAO, J. T. - GAO, X. A. 2018. Identity constructions of ESP teachers in a Chinese university. English for Specific Purposes, vol. 49, issue 1, pp. 1-13. ISSN: 0889-4906

TAO, J. - GAO, X. 2017. Teacher agency and identity commitment in curricular reform. Teaching and Teacher Education, vol. 63, pp. 346-355. ISSN: 0742-051X

TRENT, J. 2010. Teacher education as identity construction: Insights from action research. Journal of Education for Teaching, 36(2), 153-168. ISSN: 1360-0540

TRENT, J. 2015. Towards a multifaceted, multidimensional framework for understanding teacher identity. In Y. L. Cheung, S. B. SAID, - K. PARK (Eds.), Advances and current trends in language teacher identity research, pp. 44-58. Abington: Routledge. ISBN: 9781138025363

TSUI, A. 2003. Understanding expertise in teaching. New York: Cambridge University Press. ISBN: 9780521635691

TSUI, A. 2007. Complexities of identity formation: A narrative inquiry of an EFL teacher. TESOL Quarterly, vol. 41, issue 4, pp. 657-680. ISSN:1545-7249

TSUI, A. B. 2005. Expertise in teaching: Perspectives and issues. In JOHNSON, K. (Ed.), Expertise in second language learning and teaching, pp. 167-189. New York: Palgrave Macmillan. ISBN: 9781403920966

WENGER, E. 1998. Communities of practice: Learning, meaning, and identity. Cambridge university press. ISBN: 9780521663632

WENGER, E. - MCDERMOTT, R. A. - SNYDER, W. 2002. Cultivating communities of practice: A guide to managing knowledge. Harvard Business Press. ISBN: 9781578513307

WHITSED, C. - VOLET, S. 2013. Positioning foreign English language teachers in the Japanese university context. Teachers and Teaching, vol. 19, issue 6, pp. 717-735. ISSN: 1354-0602

WIDDOWSON, H. G. 1979. Explorations in applied linguistics. Oxford: Oxford University Press.

WU, H. - BADGER, R. G. 2009. In a strange and uncharted land: ESP teachers' strategies for dealing with unpredicted problems in subject knowledge during class. English for Specific Purposes, vol. 28, pp. 19-32. ISSN: 0889-4906

XU, Y. 2014. Becoming researchers: A narrative study of Chinese university EFL teachers' research practice and their professional identity construction. Language Teaching Research, vol. 18, issue 2, pp. 242-259. ISSN: 1362-1688

YUAN, R. - BURNS, A. 2017. Teacher identity development through action research: A Chinese experience. Teachers and Teaching, vol. 23, issue 6, pp. 729-749. ISSN: 1354-0602

ZABETIPOUR, M. - BAGHI, B. A. 2015. The impact of EFL teachers' years of experience on their cultural identity. Theory and Practice in Language Studies, vol. 5, issue 2, pp. 330-335. ISSN 1799-2591

ZAND-MOGHADAM, A. - MEIHAMI, H. 2016. TEFL teachers' and non-TEFL teachers' perceptions on the relationship between SLA research and language pedagogy. Journal of Language and Cultural Education, vol. 4, issue 3, pp. 233-256. ISSN: $1339-4584$ 
ZUENGLER, J. - MILLER, E. 2006. Cognitive and sociocultural perspectives: Two parallel SLA worlds? TESOL Quarterly, vol. 40, issue 1, pp. 35-58. ISSN:1545-7249

Words: 10421

Characters: 67769 (37,75 standard pages)

Professor Naser Rashidi, PhD, TFEL,

Department of Foreign Languages and Linguistics,

Shiraz University,

Iran

naser.rashidi@shirazu.ac.ir

Dr. Hussein Meihami, PhD, Applied Linguistics

Department of Foreign Languages and Linguistics,

Shiraz University,

Iran

hussein.meihami@yahoo.com 